ラーゲンを有する組織が炎症性に障害される自己免疫疾 患である.今回我々は両耳介軟骨炎, 右感音難聴, めま い，鞍鼻，喉頭気管軟骨炎による気道狭窄をきたした 1 例を経験した。ステロイド剤内服と気道狭窄に対し気管 切開を行い現在まで経過良好だが今後も慎重な経過観察 が必要である. 質問 坂井邦充(名市大)。現在の治 療状況は。応答 ステロイド内服治療を内科管理下 で行っている. 本症例では免疫抑制剤の使用はしていな い. 文献的に㹥ステロイドの他, 免疫抑制郕, 抗アレル ギー剤，抗らい殽，の使用の報告がある。

喉頭全摘後の音声再建におけるボイスボタンの

有用性一局所麻酔下での 2 期的再建について一
○藤本保志・長谷川泰久 - 松本 昇 - 竹内秀行 菅沼良規・中山 敏・松浦秀博

(愛知県がんセンター)

TEシャント用のプロテーゼとしてボイスボタンを導 入した。半年にわたる長期留置が可能であり患者負担と 交換時の危険を軽減できた。 また，2期再建は一期的な シャント造設をためらう場合も安全に施行でき，外来で の局所麻酔下の手術が可能であった．対象と方法：喉頭 全摘後の患者 9 例に局所麻酔下に TE シャントを造設, ボイスボタンを留置した。結果：9名中 6 名は良好な音 声で電話による会話も可能である.

\title{
第71回京滋合同地方部会
}

\author{
平成10年12月12日（土）一京都府医師会館大ホール
}

当科にわける CF-LV rescue 療法の分析

○駒田一朗・永原國彦・森谷季吉・浅井俊一郎

山崎萬里子（国立京都）

CDDP，5-FUに少量ロイコボリン併用した化学療法 を主として adjuvantとして採用しているが，その効果 を下咽頭癌, 中咽頭癌について検討した. Adjuvantとし て遠隔転移を25例中 4 例に認めただけであった。Neoadjuvant としてはPR 以上の有効例は 8 例中 6 例認め た。副作用は口内炎が多かったが重篤な骨髄抑制は 4 例 に認めただけであった。 3 年粗生存率は下咽磌癌では $59 \%$ ，中咽頭癌では46\%であった。

\section{UGIE におけるルゴール不染部の評価}

○森谷季吉・永原國彦・浅井俊一郎・駒田一朗

山崎萬里子（国立京都）前川高天（同・消化器科）

当科で治療した頭頸部癌患者で上部消化管内視鏡検査 (特に食道のルゴール染色)を施行したものに関して，ル ゴール不染部, 重複癌の頻度などを検討した。ルゴール 染色を145名（211件）に施行した。ルゴール不染部を下 咽頭・食道癌の 4 割, 喉頭, 中咽椇癌の 3 割に認めた. また約 1 割に上部消化管の重複癌を認めた。このことよ りルゴール染色は，頭頸部癌患者の重複癌の検索に有効 であると考えた。質問 河田了(京都第一赤十字). 下咽頭癌の亜部位で重複癌に頻度の差があるか．応 答 下咽頭癌の亜部位で食道重複癌の頻度は変わってく ると思われるが，今回検討していない. 質問 丁 剛(京府医大). ルゴール不染部からの生検での dysplasiaについての検討はどうだったか。応答 不染部の組織はほとんど正常か炎症で，異型上皮は少な
かった。

\section{当科における喉頭癌 $\mathrm{T} 1$ 症例に対する 放射線治療の検討}

○全 一・信原健二・上田 大・三牧三郎

(京都市立)

一次治療として，根治的放射線治療を施行した喉頭癌 T1 症例29例について検討した。喫煙率は91.4\%.化学療 法同時併用は12例。副作用は粘膜炎が主，骨䯣抑制は軽 微。局所制御率は $89.7 \%$. 声門上癌 ( 3 例)，化学療法併 用例 (12例) は再発 (一), 原病死 (一). 腫瘍の部位, 大きさ，病理所見などにより，局所制御不能のリスクの 高い症例に対して, 化学療法の併用, 照射中断の回避, 照射方法の工夫でさらに局所制御率改善の余地があると 考えた。買問 平野 滋(京大). 声門癌 $\mathrm{T} 1$ 症例の 再発の原因は。応答 腫瘍の大きさ，分化度が局所 制御に影響したものと考えた。質問 河田了(京都 第一赤十字). 化学療法併用の基準は何か. 応答 最 近の症例では，全身状態に異常がなければ出来るだけ併 用するようにしている。

耳下腺に発生した上皮筋上皮癌の 1 例

○野 宏・柴田敏章・㮌野香里・中井 茂

福島龍之・河田了(京都第一赤十字)

上皮筋上皮癌は組織学的に上皮と筋上皮の細胞が 2 相 性の増殖を示す比較的まれな低悪性癌とされている。今 回我々は術前診断に苦慮した耳下腺上皮筋上皮癌症例を 経験したので診断過程における反省と共に報告した。患 者は78歳男性. 左耳下部腫瘤を主訴に当科受診. CT, 超 音波，FNA， ${ }^{99 m} \mathrm{~T}$ c シンチで良性腫瘍を疑い左耳下腺浅 
葉切除術施行. 病理組織診断で上皮筋上皮癌の診断にて 術後放射線治療施行. 現在腫惶の再発なく経過観察中で ある。質問 楯谷一郎(京大)。筋上皮癌の診断には 免疫組織学的に神経原性腫瘍の除外が必要と思われる が. 応答 神経原性腫瘍に特異的な免疫染色も行っ たが，陰性であった。

\section{多結節性甲状腺中毒症の遺伝子变異の検索}

○花満雅一・北西 剛・桜井弘徳・北野博也 北島和智（滋賀医大）

多結節性甲状腺中毒症で, 遺伝子変異の検索を行った。 症例は70歳女性で，甲状腺内に結節が複数あり，それら に一致してシンチグラムで強い取り込みを認め, TRAb, $\mathrm{TsAb}$ が陰性であり多結節性甲状腺中毒症と診断，手術 を行った．凍結切片標本より DNA を抽出し PCR 法で 増幅，サブクローニング後シークエンスを行い，正常遺 伝子と比較した。今回検索した過去に変異の報告のある, TSH レセプタ一遺伝子 exon 10, Gs $\alpha$ 遺伝子 exon 8, 9 には変異は認められなかった。欧米では $27.88 \%$ と高率 に変異を認めるようだが, 本邦での変異の報告は現在ま でない，その原因は不明だが，甲状腺癌での遺伝子変異 もヨード久乏地域で高いという報告もあり，ヨードの環 境が変異の頻度に影響している可能性があると思われ た. 質問 安里 亮(京大). 術前の甲状腺機能のコ ントロールはどのようにしたか. 応答 術前にメル カゾールの投与を行い機能を正常化してから手術を施行 した。

\section{気管傍に発生した異所性甲状腺腫の 1 例}

○小田直治・玉木久信・藤本康子 (京都桂)

気管傍に発生した異所性甲状腺腫を報告した。症例は 54歳女性で頸部腫瘤を主訴に受診, 穿刺細胞診で腺腫様 腺腫と診断し手術施行したところ甲状腺下極の気管傍に 存在する異所性甲状腺であった。甲状腺は大部分が甲状 舌管から発生するが，一部は第四鰓蛪からも発生すると いわれている．この症例では第四鰓褧由来の甲状腺の癒 合不全と考えられた。質問 庄司和彦(京大)。この 症例はむしろ縦隔甲状腺腫と考えられるが。応答 縱隔甲状腺腫も第四鰓囊由来と考えられる.

\section{術後性副甲状腺機能低下症に対する}

\section{$1 \alpha, 25(\mathrm{OH})_{2} \mathrm{D}_{3}$ の使用経験}

○結城和央・北村守正・林 正彦

(滋賀県立成人病センター)

甲状腺全摘出術後の副甲状腺機能低下症に対し当科で は1995年までは主に $1 \alpha \mathrm{OHD}_{3}$ とカルシウム剤でコント ロールしていたが， 3 年前から外来レベルで $1 \alpha, 25$ $(\mathrm{OH})_{2} \mathrm{D}_{3}$ 単独投与に切り替えたところ, それまで何年も の間ビタミン $\mathrm{D}$ 剂とカルシウム剤の内服を続けてきた患
者の PTH 值が上昇し，最終的にビタミン D郕の内服を 終了できたケースが多くみられた。質問 河田了 (京都第一赤十字)。 $1 \alpha 25(\mathrm{OH})_{2} \mathrm{D}_{3}$ による過剩症は生じ たか. 応答 定期的に $\mathrm{Ca}$ 值を測定していれば高 $\mathrm{Ca}$ 血症は避けられる。

\section{慢性甲状腺炎をべースに発症した甲状腺腫}

O丁 剛・木村隆保・四/宮 隆・島田剛敏

村上 泰（京府医大）

慢性甲状腺炎（橋本病）をべースとした甲状腺腫 4 症 例を経験した。(1)橋本病十覀急性甲状腺炎，(2)橋本病十 腺腫様甲状腺腫，(3)橋本病十乳頭癌，(4)橋本病十腺腫様 甲状腺腫十乳頭癌の 4 例である。橋本病がベースにある と, 触診や画像診断が分かりにくいが, 超音波+FNA 比較的有用な診断法と考えた。また橋本病に合併した甲 状腺癌の予後は, 癌単独よりもよいという報告もあり, 取り扱いにはさらに検討が必要と考えた。

\section{緊急気管切開後に生じた照下障害の 1 症例 \\ ○加藤尚美 (京都南) 藤本康子・玉木久信 小田直治（京都桂） \\ 巨島文子 (京都第一赤十字・神経内科)}

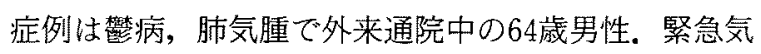

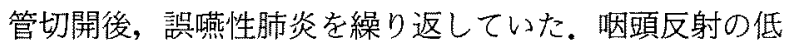
下以外異常所見は認めず。喉頭は低位で挙上制限があっ たため, 気管口周囲の線維化の除去と喉頭つり上げ術を 施行. その後喉頭の可動性は改善し現在與下訓練中であ る。本例の䜩下障害は向精神病薬の影響もあるが，輪状 軟骨損傷とその後の長期間の下顎前屈状態が喉頭の挙上 制限をきたす線維化を生じたためと考えられる。質 問 久 育夫(京府医大)。結果的に効果を認めたのは, 洀痕除去術加, 喉頭挙上術加。応答 気管口周囲の 瘢痕除去が有用であった。

\section{睡眠時無呼吸に対する歯科装具治療}

○森田武志・藤木暢也・倉田響介（京大）

歯科装具は下顎を前突位に固定することで下顎の後退 及び舌根の沈下を防ぎ，上気道の閉塞を防止する．睡眠 時無呼吸中等症以下の13例を対象に装用前後の ODI の 変化を检討した。装用により全例改善を示したが，なか でも10例で装用後 ODI10以下と著明な効果がみられた。 他の治療法と比較して, 簡便で侵襲もほぼなく, 外来通 院のみで作製・調整出来るという利点があり，中等症以 下の睡眠時無呼吸に対して有用な治療である。質問 大前 隆(京耳会)。この歯科装具は使用中にはずれて異 物になったことはないか. 応答 経験していない。 質問 久 育夫(京府医大). 装具の不自由さはどの程度 か. 応答 装用後の違和感は約 1 力月以内に消失し ている. 
成人 $\mathrm{T}$ 細胞白血病に合併した喉頭放線菌症の 1 例 ○安田 誠・丸山 晋・山道 至（近江八幡市民） 今回我々は初診時喉頭悪性腫演を疑い, その後の検査 で喉頭放線菌症の診断を得た 1 例を経験した。診断は局 麻下生検ではつかず喉頭直達鏡下生検にて確定診断を得 た。また血液検查にてリンパ球分画の異常増加を認めた ため当院内科にて精査したところ成人 T細胞白血病によ る低免疫状態に合併した喉頭放線菌症と最終診断を下し た. 治療は PCGの点滴静注が奏効し菌塊の消失をみた。

Omohyoid muscle syndrome 症例

○池田享史・片岡英幸・園田 聡・北嶋和智

（滋賀医大）佐伯紀子（九谷病院）

omohyoid muscle syndrome は䠢下時に肩甲舌骨筋に 一致して膨隆が形成される原因不明の疾患群である．症 例 1 は50歲女性. 主訴は咽喉頭異常感である. 症例 2 は 25歳女性. 主訴は嚥下時左頸部膨隆である. 2 症例とも 瞬間的に頸部膨隆を認めるのみで，疼痛がなかったため 治療はせず経過観察となった，膨隆の原因として肩甲舌 骨筋の解剖学的位置異常の存在が疑われた。質問 薬物療法で改善のみら执報告はないか。応答 薬 物療法ではミオナールが有効との報告がある.

深頸部膿瘍にて発生した慢性肉芽腫症の 1 幼览例

○内田真哉（公立南丹）宇野敏行（京府医大）

慢性肉芽腫症は食細胞の殺菌作用の主体である活性酸 素の産生に障害をもつ食細胞機能不全症であり，幼児期 よりカタラーゼ陽性 $\mathrm{H}_{2} \mathrm{O}_{2}$ 非産生性の細菌による反復 性, 遷延性の感染症を引き起こす。本邦では約 200 人の患 者がいるが，耳鼻咽喉科領域からの報告は皆無である。 今回, 難治性深頸部膿瘍のため免疫不全が疑われた幼児 に対して, 過酸化水素産生能試験を行い, 常染色体劣性 遺伝でチトクロームb 陽性の慢性肉芽腫症と診断し得た 症例を経験し報告した。

\section{当院における下鼻甲介粘膜下高周波電気凝固術}

○福島一登（舞鶴赤十字）

豊田健一郎・板東秀樹・只木信尚（国立舞鶴）

薬物を中止できない通年性アレルギ一性鼻炎, 肥厚性 鼻炎の鼻閉を改善させる目的で23例に対して下鼻甲介粘 膜下電気凝固術を施行した。期間は平成 9 年 8 月からの 14 力月間, 年齢は11歳から55歳, 性別は男性12例, 女性 11例である. 術後 2 週間目以降に薬物使用の軽減により 著効, 有効, 不変, 悪化の 4 段階で評価し, 著効, 有効 あわせて21例 $(91.3 \%) に$ 効果を認めた。質問 加藤 尚美 (京都南). 著効例についての持続期間はどうか、電 極刺入は何力所で行ったか。応答 現在のところ14 カ月持続している。一側下鼻甲介に 2 力所刺入している. 追加 只木信和(京耳会)。1 月月で再発した症例がある
とのことだが，凝固が弱すぎるものと思う．私は下甲介 前端及び中央に数力所ずつ凝固している。

通年性アレルギー性鼻炎に対する点鼻薬 単独治療の試み(第 2 報)一患者に対する

説明を中心として一

○河田了・柴田敏章・中野 宏・栢野香里

中井 茂・福島龍之 (京都第一赤十字)

当科では，通年性アレルギ一性鼻炎に対して外用ステ ロイドを中心とした治療を行っている，しかし，吸入ス テロイドは，正しい使用法が案外難しく，実際十分な効 果が現れていない症例の中には使用法の嵒りによるもの が少なくない.そこで，アレルギー性鼻炎患者に対して， 吸入ステロイドの使用法を中心に十分説明し，説明前後 でアンケート調査を実施して，その理解度を調查，検討 した.

\section{塞栓術を施行した上顎洞血瘤腫症例}

○佐渡文彦・松波達也・坂口博史・増田信弘

日向 誠・大島 涉・堀 昇子・高田 憲 (京都第二赤十字)

術前に塞栓術を施行した上顎洞血箅腫手術症例を経験 した. 主訴は複視，CTにて上顎洞内に眼窩下壁を圧迫す る腫瘤陰影を認めた。生検では血管性病変を疑われた。 動脈造影で腫瘤辺縁に血管增生を認めた，腫瘤の栄養血 管と思われた眼窩下動脈と下行口蓋動脈を塞栓した。塞 栓術 6 日後に腫瘤摘出術を施行した。術中出血は $86 \mathrm{ml}$ であった。術直後より複視は改善した。病理所見は炎症 性病変に出血を伴ったもので，血瘤腫と診断した。

当科における内視鏡下鼻内手術の術後成績

○中茾 茂・柴田敏章・中野 宏・栢野香里

福島龍之・河田了(京都第一赤十字)

過去 3 年半に慢性副鼻腔炎に対して施行した内視鏡下 鼻内手術の成績を検討した，自觉症状の改善，手術結果 に関しアンケート調査を行い集計した（186例)。他覚的 改善度は術後 6 力月時での CT, 内視鏡所見から検討し た (195例)．自覚症状の改善度は70-90\%，手術結果の 満足度は $85 \%$ と良好であった。 $85 \%$ 症例は他賞的改善 度で完全, 部分治癒を示したが，0 歳一9歳群で $80 \%$, 気管支喘息合併症は $45 \%$ と高い再発率を示した。質 問 藤木暢也(京大)，喘息合併例の術後成績が不良であ る報告が多いが，術後，薬剤はどのようなものを使用し ているか. 応答 術後 $3-6$ 力月間，マクロライド 戍投与を行う。アレルギー性鼻炎症例には，抗ア剂，ス テロイド点鼻を併用する，喘息合併例は内科的治療を優 先する。

術前重症度からみた ESS 術後成績の検討

○鈴木治子・出島健司・濱 雄光・石坂成康 
宮崎 信・安田繁伸・村上 泰（京府医大）

鼻茸の大きさからみた重症度が ESS 術後成績の予後 不良因子か否かについて検討を行った. 当科で66症例106 側を鼻茸の大きさで分類し, 術後 CT-鼻内所見にて改善 度を評価した。 その結果, 鼻茸の大きさと術後成績との 間に相関は認められなかった。従って鼻茸の存在・大き さといった術前重症度は ESS 術後成績の予後不良因子 として大きく関与していないことが明らかとなった。 質問 中井 茂(京都第一赤十字). アレルギー素因の合 併例では，好酸球浸潤などについて病理学的検討を行っ ているか. 応答 アレルギー素因の有無にかかわら ず, 鼻茸中の好酸球浸潤の有無と程度, EG 2 抗体を指標 として活性化好酸球の割合を検索している。

鼻腔 solitary fibrous tumor $の 1$ 例

○小田直治・玉木久信・藤本康子 (京都桂)

鼻腔に発生した solitary fibrous tumor を報告した。 症例は34歳男性. 1 年前から左鼻閉と左煩部痛を主訴に 受診。左鼻腔を閉塞する腫瘤を認め, 全摘出した。病理 学的検查でSFT との診断であった。免疫組織学的にはビ メンチン, S-100 が陽性で,ケラチン, SMA は陰性であっ た. 文献的には頭頸部領域での報告はまれで, 自験例を 含め18例, うち15例が鼻副鼻腔, 上咽頭領域であった.

鼻腔に発生した悪性青色母斑の 1 例

○吉井美千子・大脇成広・田中 寛（市立長浜） 吉田芳信（同・形成外科）北嶋和智（滋賀医大） 小澤博史 (小澤耳鼻科)

症例は73歳女性で, 右鼻腔内腫瘤と鼻閉を主訴とした。 当科で確定診断される前に近医で 2 回生検されていた が，青色母斑との診断だった。腫瘤は下鼻甲介を中心に 存在し兏白色〜黒色を呈していた，外鼻皮䖉，上頡洞内 側壁にも浸潤していたため, 顔面皮膚も含め約 $2 \mathrm{~cm} の$ marginをつけ摘出した。術後は悪性黑色腫に準じた DAV 療法を 2 クール行った。術後 4 力月現在再発, 転移 を認めていないが,ささらに化学療法を続ける予定である. 質問 出島健司 (京府医大). 悪性黒色腫との臨床的特徵 の差は。応答 視診上，区別はつかない。質問 玉木久信(京都かつら)。腫煌は皮膚原発か。粘膜原発か。 応答 下鼻甲介 (粘膜) 原発と考元る。

\section{上顎 meningioma $の 1$ 例}

○浅井俊一郎・永原國彦・森谷季吉・駒田一朗 山崎萬里子（国立京都）桶口佳代子（同・病理部）

症例は24歳男性. 歯痛と頉部腫脹を主訴に歯科受診し 紹介にて当院受診した.CT, MRI から良性腫瘍を考元歯 数部切開にて摘出術施行した。病理所見で上顎洞ではた いへんまれな psammomatous type の異所性㗙膜腫と 判明した。画像と文献考察を加えて報告した。
矢澤代四郎(滋賀医大)。術前に病理的診断はついていた か. 応答 術前の病理診断はつかないまま, 手術を 施行した.

脊髄小脳変性症が疑われた Chiari 奇形の 1 例

○浅野純志・山本 聡・林戸 功・増田有加里 安野元眮・村上匡孝・立本圭吾・谷村史子 高田 憲（京府医大）

発症より20年に及ぶ長い臨床経過より春随小脳変性症 が疑われた Arnold-Chiari 奇形（I 型）の 1 症例を経験 した。著明な失調歩行と下眼瞼向き自発眼振が認められ， 追従眼球運動では dysmetry を呈した。また温度眼振検 査では固視抑制の減弱を認め, 下部脳幹脳神経障害と鍾 体路障害を合併していた。さらにMRI 検查で確定診断 を得た。神経耳科学検查は MRI と共に診断に有用であ ると考えられた。質問 矢澤代四郎(滋賀医大)。右 側優位の神経症状が出ているが, 画像診断で左右差の所 見はあったか. 応答 頭部 MRIにて明らかな左右 差は認められなかった。

\section{鼓室形成一次手術前後の聴力变化}

○坂口博史・佐渡文彦・松波達也・増田信弘

堀 昇子・高田 憲・日向 誠・大島 涉 (京都第二赤十字) 寺薗富朗 (京耳会)

一次手術前後の聴力変化につき検討した. 真珠腫性中 耳炎31例, 慢性化膿性中耳炎 6 例の計37例を対象とした。 術前気導 $41 \mathrm{~dB}$, 術後気導 $45 \mathrm{~dB}$ で平均 $4.3 \mathrm{~dB}$ の聴力低 下を認めた。耳科学会判定基準によると気導聴力 $40 \mathrm{~dB}$ 以内 17 例 ( $46 \%$ ), 気骨導差 $20 \mathrm{~dB}$ 以内 8 例 (22\%), 聴力 利得 $15 \mathrm{~dB}$ 以上 5 例 (14\%), 成功例 20 例 (54\%) であっ た、アブミ骨上部構造が残存した場合には成功例が多 かった。質問 立本圭吾(京府医大)。段階手術の適 応は。応答 tynpanic sinus に真珠腫が存在する場 合，段階手術を選択することが多い．

小脳膿瘍を伴った中耳真珠腫の 1 例

○岡野高之・高橋晴雄・長谷部誠司・船电和雄 (京大)

症例は39歳男性. 右下痛を主訴とし側頭骨 CT で広範 な後頭蓋窩の骨破壤が認められた。脳 CT で小脳膿湟が 認められたため, 緊急開頭排膿㧍よび中耳手術を行った。 現在術後 15 力月で後遺症なく, 聴力も良好に経過してい る。耳性小脳膿瘍は，中耳炎の治療で典型症状が隠蔽さ れるため, 突如神経症状を来した後は, 脳幹圧迫を来し 予後は悪い. 進展した中耳真珠腫の合併した小脳膿場で は, 早期の脳 CT と手術が不可欠である。質問 村上 匡孝(京府医大). 膿湟の形成に外耳道生検は影響なかつ たか. 応答 関連はないものと考える.

アンケート調査からみた人工内耳使用者の満足度 
○古家野智子・森田武志・船曳和雄・藤木啺也 内藤 泰 (京大)

当科で人工内耳埋込手術を行った言語習得後失聴成人 36例のアンケート結果より，患者の満足度について調べ た。手術を受けて「大変良かった」「少しは良かった」「あ まり変わらなかった」と答えたのはそれぞれ $80 \% ， 14 \%$ ， $6 \%$ あっった，満足度は，単音節の聞き取りの改善より も，実際に会話が出来るかどうかにかかっており，高噛 であってかつ失聴期間が長い場合に満足度が低くなる傾 向があった。

\section{当科におけるムンプス難聴の検討}

○神前英明・鈴木幹男・北西 煀・北野博也 矢澤代四郎・北嶋和智（滋賀医大）

MMR ワクチンの任意接種化により，ムンプス難聴の 羅患率が増えると予想される。ムンプス難聴新鮮例 6 例 の治療経過, 長期予後を検討した. 全例一側性高度難聴, 浮動性眩暈があり，4例で温度刺激検查で反応低下して いた，笑発性難恥に準じた治療を行ったが，聴力の回復 はなかった，長期経過を追えた 5 例中，1例で頭位性め まいが残存した，他例ではめまいは消失したが，1例で 同側型遅発性内リンパ水腫の発症をみた。質問 内藤 泰 (京大). ムンプス難聴後 9 力月で遅発性内リン パ水腫の例を示しているが，このような早期の発症は一 般的か. 応答一般的にはもう少し遅く発症してい るが，同様な時期の発症の報告もみられる。

補聴器 (HA) 販売システムにおける

\section{耳鼻咽喉科医の役割}

服部 浩 (京都市)

現在年間50万台の $1 / 2$ は HA 販売店協会店, $1 / 2$ は 2-30000実体不明店で売られ，耳鼻科の関与は前者の $30 \%$ ，身障用を除くと $10 \%$ に過ぎない. 購入者の $90 \%$ は 60歳以上で HA 候補者の 5-600万人は広告, 口込み頼り のため不適正販売の被害が後を絶たない. 認定 HA 専門 店, 病院 HA 外来(言語聴覚士を含む), 耳鼻科医院が緊 密な HA 供給システムを作り責任あるサービスを保証 し「HA なら最寄りの耳鼻科へ」の一般常識化を目標と し，不適正販売の自然消減を計らねばならない.

\section{成人式を迎えた耳音響放射}

田中康夫 (京耳会)

耳音響放射(OAE)に関する最初の論文が, D.T. Kemp によって米国音響学会誌に発表されてから丁度20年を経 過した。日本では OAEの測定機器が今年になって漸く 保険適用の承認を得, OAE による他覚的蝸牛機能検査法 が日の目を見るに至った。OAEの最近の研究動向, 臨床 応用の進展，および新しい測定装置について説明した。 また，OAE検查によって明確にされた新たな疾患概念，

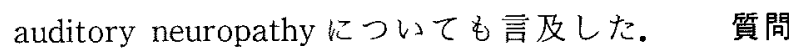
安野友博(京耳会). アクティブフィードバック機構と遅 延性のCM との関連性について。応答 Wilsonの 研究もあるが，遅延性の CM とは，潜時が長いこと，入 出力の関係が飽和すること，酸素依存性であることから 互いに対応があるものと考えられる。

\section{第118回福岡県地方部会}

\section{平成10年12月 5 日（土）パピヨン 24 ズスール}

実験的内リンパ水腫モルモットの CAPに ついて一第 1 報一

○近藤 毅・宮城司道・森園哲夫（福岡大筑紫） 池田宏之・白石君男（福岡大）

正常モルモットにおける刺激音のパラメータ変化によ るCAPの閶值について検討した。ついで, 内リンパ水腫 モルモットを作製し，術後 6 力月〜10力月の CAPにつ いても検討した，正常耳において repetition rateおよび rise timeが増加するにつれて CAPの amplitude は減 少した. Plateau は CAPに影響を及ぼさなかった. 水腫 耳の CAP は正常側と比べ amplitude は低下, N1の latency は延長しており，CAPの閾值によるオージオグ ラムは全周波数で聴力低下を示した。質問 藤吉 達也(産業医大)．1）本疾患モルモットに行動上の変化
はみられるか．2）内リンパ水腫の状態は永久的なもの か. 3）グリセロール投与による病態の変化は認められ るか. 応答 1) 肉眼的に平衡障害は認められなかっ た，2）内りンパ水腫は改善されない，3）グリセロール には反応しない。

内頸静脈圧迫による中耳環境の变化について

$\bigcirc 太$ 田黒 元・坂田俊文・文丸文秀 $\cdot$ 白石君男 加藤寿彦（福岡大）

内耳圧の上昇が中耳伝音系に及ぼす影響を考察する目 的から, 正常耳（16名30耳）に対し内頸静脈圧迫にて内 耳圧を上昇させ，ティンパノグラム，スウィープティン パノグラムの変化を記録，検討した，その結果，内耳压 上昇によってピークプレッシャーの陽圧方向への変化, スタティックコンプライアンスの低下，耳小骨連鎖の固 
着傾向が確認された。感音難聴における耳門塞感の発現 機序を考察する上で, 與味ある知見と考えられた。質 間 中川尚志(九大). 中耳インピーダンスのピークが陽 圧にシフトするのは何故か. 応答 理由は不明であ る. 質問 井之口 昭(九大)。頸静脈圧迫で耳閉感 を訴えたのは，どのくらいの割合か. 応答 2 耳て あった。

\section{シスプラチンとカルボプラチンにおける}

聴覚障害の相違

○花栗 誠・因幡 剛川・藤田雅子・吉田雅文 牧嶋和見（産業医大）

シスプラチンとカルボプラチンによる聴覚障害につい て標準純音聴力検查と高周波数域聴力検查を用いて，検 討を行った. シスプラチン投与を受けた 35 耳中 3 耳に標 準純音聴力検査において聴覚障害を認め，そのうち 2 耳 では高周波数域聴力検査においてより早期に域值の上昇 が観察された。これに対して，カルボプラチン投与を受 けた 9 耳では，高周波数域聴力検査を含めて聴覚障害在 認めなかった. カルボプラチンはシスプラチンに比べ聴 覚障害の頻度は少ないとされているが，大量投与時等に は聴覚障害に注意す心゙きであり，その検出には高周波数 域聴力検査が有用と思われた。質問 中川尚志(九 大).カルボプラチンは内有毛細胞,シスプラチンは外有 毛細胞を障害と機序は異なるが，併用についての議論は なりたつか、応答 カルポプラチン投与によりヒト において外有毛細胞が障害されないという否定的な報告 はない. 質問 藤野睦子(九大)，1）化学療法前に中 耳炎等の異常があった場合，全例正常域であったか，2） 聴覚低下があった場合，その後の化学療法は他剤に変更 したか. 応答 1）耳疾患の既往のある症例や，初診 時難聴を認めた症例は除外した．2）聴覚障害を認めた 症例では聴力低下の程度は全例軽度で, 自覚症状も認め ないため, 経過観察を厳重に行い投与を続けた。

\section{当科における人工内耳の経験}

○藤野睦子 - 中川尚志 - 安田知久 ・ 野口敦子 大庭典子・小宮山荘太郎（九大） 岩元正広 (鹿屋市) 井上裕章 (福岡市) 小宗静男 (宮崎医大)

1995年 2 月以降当科で人工内耳埋め込み術を施行した 言語習得後失聴者 10 例の術後の聴取能を検討した。単音 節弁別能は読話が 2 から $34 \%$ ，人工内耳が $10 か ら 46 \% ，$ 人工内耳十読話が 28 から $72 \%$ だった。単語了解度は読話 が 2 から $24 \%$ ，人工内耳が 6 から $46 \%$ ，人工内耳十読話 が18から $76 \%$ だった。文了解度は読話が 0 から $28 \%$ ，人 工内耳が 0 から $62 \%$.人工内耳十読話が 4 から $84 \%$ だっ た. 7 症例では言語聴取能は改善した。

質問 加藤
寿彦(福岡大)．術後成績が壾かった 3 症例の術前の言語 機能はどうだったか. 言葉の乱れのひどいものや，保有 言語の少ないものは良い成績が期待できないので注意を 要する. 応答 症例 5 のみは, 衍前より言葉の乱れ があった. 今後は，言語習得後失聴者であり，言語の表 出の乱れていない方を適応としていきたい. 質問 江浦陽一(福岡大)。顔面神経麻痺は術後どれくらいで出 現したか。またその原因は。応答 術後顔面神経麻 痺を起こした 2 例は奇形のため, 術中顔面神経を露出し, 術直後より顔面神経麻痺が出現した。1 例は 2 週間で, 1 例は 1 力月で改善した. 追加中川尚志(九大). 顔面神経麻痺が生じた症例は，生来顔面神経への前方人 の変位が認められた。このため, 電極挿入の障害となっ ていた。

\section{手術を施行した口蓋骨外骨症症例}

○橋田光一・森尾 崇・得居直公・藤吉達也 牧嶋和見（産業医大）

口蓋隆起（外骨症）は，上顎骨口蓋突起一口蓋骨間の 縫合線と口蓋骨縫合線とが十字に交差する部位に発生す る辺緑性骨過剩形成である，症例は42歳女性. $25 \times 20 \times$ 12 (高) $\mathrm{mm}$ の口蓋隆起によって違和感と食物残渣の停 滞を訴えたため手術を施行した。隆起骨の削開に際して はその後半部分が口蓋骨の一部と共に摘出され，鼻腔底 側の骨膜が露出したため口蓋粘骨膜弁にて被覆した。創 治癒は良好で症状も消失した。詳細な手術手技の記載は 文献上見られず，摘出時に口蓋骨が破損しやすいことを 手技上の注意点として強調した。質問 加藤寿彦(福 岡大)、口蓋骨に穴が開いても㐭側の粘膜が正常なら特 に粘膜移植は必要ないと考えられるが。応答 慺孔 形成にて再手術が必要ないように一期的に行う方法を選 択した。質問 冨田吉信(九州がんセンタ一)。手術 の適応, 切除範囲の決定はどういう基準で行えば良いか. また再発の可能性はあるか。応答 何らかの症状を 訴え，患者が手術を希望した時適応となる。切除範囲は， 本症例では食物残渣が停滞することがないような形態に することを目標とした，外骨症であるため，口蓋骨まで 切除する必要はない. また, 本疾患の発生学的病態を考 えると，容易に再発することはないと考えられる。

\section{舌に発生した分離腫の 1 症例}

○古野 均・梅野博仁・宮嶋義巳・中島 格 (久留米大)

舌背部に生じた，まれな軟骨性分離腫の 1 症例を報告 した。症例は18歳の男性で, 主訴は舌背の無痛性腫瘤で あった。病歴は1991年頃に口腔内の違和感を自覚し, 検 診で舌背部の無痛性腫瘤を指摘1998年 6 月12日に当科を 受診した。舌背部正中に直径 $12 \mathrm{~mm}$ の粘膜下腫瘤を認 
め, 舌腄崵の診断で1998年 8 月18日，局所麻酔下に炭酸 ガスレーザーを用いて腫湟切除を行った。摘出した標本 の割面で筋組織内に白色の軟骨組織を認め, 軟骨性分離 腫と診断した。本邦に扔ける舌分離腫は, 軟骨性 6 例, 骨性11例，骨軟骨性 3 例の計20例が報告されていた。 質問 山本智矢(九大). 今回の手術でレーザーを使用し た理由は. 応答 術前に良性悪性の診断はついてな く，仮に悪性であっても周囲の血管やリンパ管を凝固封 印し，少量の出血で切除できる炭酸レーザーを使用した。 質問 江浦陽一(福岡大). 舌以外での好発部位は. 応答 耳鼻科領域では, 外耳, 中耳にあり，その他は卵 巣，子宮などに認められる。

\section{頸部交感神経節に発生した神経節腫の 1 例}

○田中倰一朗・稲光まゆ・稲木匠子・熊本芳彦

山本智矢・小宮山荘太郎（九大）

篠隈 淳 (同・第 2 病理)

神経節腫は後縦隔，後腹膜に発生することが多く頭頸 部領域に発生することは比較的まれである．今回，頸部 交感神経節に生じた神経節腫の 1 症例を報告した。症例 は 5 歳女児で主訴は左耳下部腫瘤。全麻下にて腫湯摘出 後，ホルネル症候群を呈し，交感神経由来と考えられ， 神経節腫の術前診断にはカラコラミン測定と MRI が有 用である.また病理組織学唡査で幼若細胞の分化傾向や， 分化の程度が混在している場合には転移，再発に留意す る必要がある。質問 冨田吉信(九州がんセンター). 1）術後合併症の回復の可能性は。2）神経切断しての完 全摘出と神経保存しての減量術の適応は。応答 1) 文献的に眼瞼下垂は軽快する報告が多い，2）再発の恐 れもあり，再手術の際に手術操作困難であると考元られ たため完全摘出した。質問 坂田俊文(福岡大)。1) 細胞診の蚜刺はこのような小児に対し，どのように行っ たか，2）腫瘤摘出時，顔面神経はどのように処理した か. 応答 1) 無麻酔で行った。2) 顔面神経は露出 していない,

\section{慢性甲状腺资の経過中に発生した甲状腺 噃様癌の 1 例}

○柴田修明・横光 智・梅崎敏郎・山下弘之 山本智矢・井之口 昭・小宮山荘太郎（九大）

篠隈 淳・白土秀樹（同・第 2 病理）

今回慢性甲状腺炎の経過中に発生した甲状腺髓様癌の 症例老経験した，近年両者の関係についての報告例があ るため多少の文献的考察を加えて報告した．質問 冨田吉信 (九州がんセンター)。術後照射の適応条件は. 応答 放射腺治療は従来無効とされてきたが，近年八イ リスク症例の術後照射は再発率の低下に有効との報告が 多い。質問 江浦陽一(福岡大)。髄様癌は散発性と
家族性に分類されるが，この症例はどちらか。また鑑別 診断としてどのような検査をしたか．腹部精査は施行し たか。応答 I-MIBG シンチ, 腹部 CT で副腎腫場 のないことは確認して扔り, 散発例と判断している. 質問 野村 和(福岡済生会)．1）慢性甲状腺炎の経過 が長いが,この間の検查の経過は，2）細胞診で良性との 判断だが，この点についての見解は。応答 1) 経 過に関しては追跡調查をしたが，詳細は不明. CEA は 8 年程前より高值で,その後も上昇している，2）細胞診は あたっていなかった可能性が高い.

喉頭進化, 哺乳類への道 内喉頭筋の生理進化一新旧発生機構論一 豊住頼一（大牟田市）

横筋が固定閉鎖筋のとき，内筋，側筋が披裂軟骨を内 転する收縮力は声帯突起部に力点を発生し，前筋との間 に前後に均衡な率引が作用する拮抗生理を成立させる。 拮抗は内喉頭筋間の連動生理によって成立する。しかも 連動生理は声帯調節と密接な関係にあるので，両生理は 新発生機構成立の 2 本の柱である。横筋が閉鎖筋のとき は両生理は成立しないので，現在，発生機楧は存在しな いことになる。なお図による捛抗生理の説明は局所の発 生理論を，表に示した連動生理の説明は中枢支配の内喉 頭筋の筋生理を示唆する。

\section{喉頭室癌の免疫組織学的検討}

○金 哲・宮嶋義巳・梅野博仁・千久和圭一 中島 格 (久留米大)

今回，我々は免疫組織化学的手法を用いて喉頭室癌の 性質とその発生母地について検討した，対象は1988年か ら1998年に当科で治療を行った喉頭室癌14例で，全例扁 平上皮癌であった，急疫染色の一次抗体には SC(分泌因 子), Keratin7 (低分子ケラチン), Keratin14 (高分子ケ ラチン)，を使用した。結果は喉頭室癌では SC は 9 例 (64\%), Keratin7は 6 例 (43\%), Keratin14 は14例 （100\%）が陽性であった．SC と Keratin7 の陽性の割合 が高いことから，喉頭室癌は腺の性質を多く有している と考えられ，腺系の細胞から発生している可能性が示唆 された。

\section{当科における上顎腫瘍症例の検討}

○菅村真由美・柴田憲助・西園万寿男・森本健三 小倉朋子・平田昭二・江浦陽一・加藤寿彦

(福岡大)

当科において治療を行った上顎悪性腫瘍一次治療例 96 例について検討を行った。疫学的には男女比は約 $3: 2$ で年噛は60歳代が最多であった。組織型は扁平上皮癌が 全体の約 $80 \%$ 占め，TNM 分類では T3，T4 の進行癌 が全体の $85 \%$ を占めていた。全体の 5 年生存率は $46 \%$ て 
あり, $\mathrm{T}$ 分類別の 5 年生存率は $\mathrm{T} 1+\mathrm{T} 2$ で $58 \%, \mathrm{~T} 3$ で 46\%，T4 は39\%であった。また，リンパ節転移を認める ものは予後不良であった．質問 井之口 昭(九大). 放射線十手術群の方が放射線十手術十化学療法群より 5 年生存率が $10 \%$ 程高いが，その理由についてどう考える か. 応答 手術+化学療法十放射線の治療を施行し たものは, 放射線十手術群に比べて Stage が高いものが 多かったためと考えている。質問 梅野博仁(久留米 大). Sarcomaを UICC 分類し, Carcinoma と混ぜて統 計をとっているが, Sarcoma は除外し, 別に統計をとる べきではないか. 応答 今回, 手術治療を基本とす る症例を対象に検討したので, Sarcomaも含めた. 今後 は除外し再統計を行いたい。

\section{耳下腺悪性腫瘍の臨床的検討}

○安松隆治・一番ケ瀬 崇・富田和英・原崇 末田尚之・平川直也・檜垣雄一郎・冨田吉信 (九州がんセンター)

1972年 3 月から1997年12月までに当科で一次治療を 行った耳下腺癌42例について検討を行った。全体の累積 5 年生存率は69\%であった. TNM 分類 (1997, UICC) に当てはめると, T別では $\mathrm{T} 1, \mathrm{~T} 2$ 例に比べて T3, T4 例 が，N別ではN-例に比べて $\mathrm{N}+$ 例が有意に予後不良で あった。 また, 病理組織別にみると, 未分化癌, 粘表皮 癌 (高悪性型) 例は, 予後不良な傾向にあった。再発率 は45\%であり，死因の多くはM死であった。質問 山本智矢 (九大). 5 年以降も成績が下降するが 10 年生存 率はどのくらいか。応答 今回 10 年生存率は算出し ていないが, 最も遅発性に再発が確認されたものは80力 月目であった。質問 倉富勇一郎(九大)。末分化癌 に対し今後予後を改善させるためにどういう方針でのぞ むか. 応答 未分化癌については，切除範囲の拡大 を第一に考えている．質問 千々和圭一(久留米大). 核出術のみの症例の治療成績はどうか.コントロールが できていれば, 何か組織型の特徴があったか. 応答 核出を行った症例のうち 2 例が粘表皮癌低悪性型であっ た。

術後性上顎囊胞に対する内視鏡手術の適応

○高瀬武一郎・山口勝矢・中島 格 (久留米大)
術後性上顎赦胞に対する治療は口腔前庭からの手術法 のみならず，内視鏡下の上䫇ドレナージ術が積極的に行 わ机るようになったが，鉷胞の数，位置等により限界も ある. 今回我々は 95 年 4 月〜 97 年 12 月までに当科で手術 を受けた 42 症例（右 16 例, 左 20 例, 両 6 例）男 22 例, 女 20例，年齢36 84歳（57歳）に対して口腔前庭経由手術 （鼻外法）と内視鏡手術（鼻内法）現時点での適応を含め ての比較検討を行った。質問 野村 和(福岡済生 会)。内視鏡手術の適応ということだが, 手術は原発巣を 治瘾せしめるのが目的で，無関係の下甲介切除や中隔手 術が適応とは言えないのではないか。応答 ご指摘 のとおりだが,最初から行う予定で施行したのではなく， 術中所見で行った結果, 全例下甲介切除を施行していた。

発声練習中に発症した特発性縦隔気腫の 1 症例

○権 徹・佐野千晶・佐野啓介 (健和会大手町病院)

今回我々は比較的まれな特発性繸隔気腫を経験したの で報告した。症例は17歳, 男性。主訴は前胸部痛, 呼吸 困難であった。本年 8 月27日，体育祭の応援練習後飲水 時に, 前胸部に裂加るような痛みを自覚, 痛みは徐久 に頸部に達し, 当院救急外来を受診し当科入院となった。 胸部 X-P 上明らかな異常所見を認めなかったが，頸部 $\mathrm{X}-\mathrm{P}$ にて縦隔から頸部に至る透亮像を認めた。 CT 上 2 日目より気腫の縮小傾向を認め, 保存的治療にて改善し, 入院より11日後退院となった. 本症例の経過観察, 治療 法の選択にCT が非常に有用であった。

生後 2 力月の女児に発生した深頸部感染症

○渡利昭彦・松吉秀武・黑田嘉紀・牧嶋和見 (産業医大)

症例恃生後 2 力月の女児で, 平成 10 年 8 月 25 日に 38 度 台の発熱があり，近医小児科で抗生剤を処方され，内服 したが軽快しなかった。 6 日後に右頸部が腫脹し, 徐々 に増大した。他院にて施行した CT 検査に扔いて，右上 頸部漕瘍腔を認め, 産業医科大学耳鼻咽喉科を紹介受 診した。即日入院し, 全身麻醉下に頸部切開排膿術㧍よ び, 抗生剤治療を行い, 術後22日目に治癋退院した。近 年まれな乳児深頝部感染症報告例を提示し, その特徵, 治療法について検討を加え報告した。

\title{
第80回宮崎県地方部会
}

\author{
平成10年12月 20 日（日）一宮崎観光ホテル
}

宮崎医大・外来・入院患者統計

○和田由起 - 大橋 充 $\cdot$ 松田圭二 ・河野浩万
加藤榮司・植木義裕・春田 厚・東野哲也 小宗静男（宮崎医大） 
外来初診患者数は1899名で例年通りであった，耳疾患 が56\%と大きく占好いた，耳疾患については，内耳疾 患では感音難聴，鶕，中耳疾患では慢性中耳炎，滲出性 中耳炎が多く，特に真珠腫性中耳炎が増加傾向にあった。 鼻・副鼻腔疾患では例年通り，慢性副鼻腔炎，稟アレル ギーが半数占めていた，腔，唾液腺疾患では耳下腺腫， 舌癌が多く，喉頭疾患では反回神経麻舫が上位を占めて いた。今年度に特徵的なことは，副咽頭間㭞腫晹の症例 である，入院統計では，例年通り耳疾患が半数以上を占 めている，今年度の特徴として耳硬化症が増加傾向にあ ることが挙げられる。鼻・副鼻腔疾患, 咽頭・唾液腺疾 患はほほ例年通りであった。今年度の死亡症例は外耳道 癌症例であった。この症例は両側外耳道癌という極めて まれな症例であった。質問 春田 厚(宫崎医大)。 昨年までの統計との違いと特徴は何か. 応答 新教 授の体制となって，前頭蓋底手術，中頭蓋底手術など新 しい手術が行われた。また副咽顗間陵腫瘍など例年にな い症例があった。

県立延岡病院入院統計（H 9．12～H10．11）

○外山勝浩・竹中美香・稻葉順子・紀井登志哉 (県立延岡)

今年の入院総計は367件であった。男性は 222 件，女性 は145件で昨年と比べ女性の増加が目立った。疾患別にみ ると, 耳疾患が $18.0 \%$, 鼻疾患が $16.5 \%$, 口腔咽頭疾患 が $41.5 \%$ ，喉頭疾患が $10.4 \%$ ，その他 $13.6 \%$ と比率的に は例年とほとんど変わりなかった。死亡退院したのは 6 例で喉頭癌 2 例, 下咽頭癌 1 例, 歯肉癌 1 例, 耳下腺癌 の再発 1 例, 悪性リンパ腫 1 例であった。質問 小宗 静男(宮崎医大)。喉頭アミロイドーシスの発生部位, 治 療, 経過はどうか. 応答 全身検索を行ったが喉頭 限局のアミロイドーシスであった。 1 例仮声帯が腫脹し ていた.今のところは嗄声のみの症状で経過観察中であ b.

\section{県立宮崎病院手術・入院統計}

(H 9 ，12 H H10. 11)

○松浦宏司・中島崇博・坪井陽子・井藤 健 南 慎一 (県立宮㱦)

平成 9 年12月から平成10年11月までの当院における手 術と入院の統計・検討を行った。手術件数は前年に比べ て微増の675件であった。真珠腫に対する鼓室形成術，ア ブミ骨手術, 咽喉頭癌手術が減少し, 鼻内篩骨洞手術, 唾液腺手術が増加している. 悪性腫湟の入院患者では中 咽頭腫陽が増加している。紹介元では宮崎市内の開業医 院からが最も多いが，耳鼻科医以外からの紹介も少なく なかった。質問 春田 厚 (宮崎医大)。悪性腫演の 紹介症例ではT分類, Stage 分類はどのような内訳か.
応答 耳鼻咽喉科の先生方からの紹介は $\mathrm{T} 1, \mathrm{~T} 2$ が多い が，他科の先生方からの紹介では進行癌が多いという印 象であった。

国立都城病院入院・手術統計

(H 9 ．12〜H10．11)

○牧元 宏・永井知幸（国立都城）

平成 9 年12月から平成10年11月までの当科における入 院は全症例 290 であった。 そのうち耳疾患が16\%で47例， 鼻疾患が23\%で67例，口腔・咽頭疾患が最多で40\%の117 例, 喉頭疾患は $8.6 \%$ で5例，その他は $12 \%$ で34例だった。 手術は耳疾患 54 件鼻疾患70件その他の疾患では良性疾患 が110件悪性疾患が46件であった.死亡総数は 7 例であっ た。質問 橋口哲美(宮崎市)。いびき患者に対する 手術法とその予後について． 応答 手術方法は，U P.P.P. (口蓋垂, 軟口蓋, 咽頭形成術)を行っている.予 後はダイエットがうまくいった患者に対しては良好な印 象である。質問 小宗静男(宮崎医大)，扁桃切除が

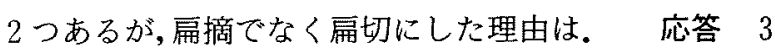
歳以下の子供に対して免疫能を残すため扁摘でなく扁切 を行った。

\section{古賀総合病院入院・手術統計}

(H 9.12 H10，11)

定永正之（古賀総合）

入院総数 210 例，手術症例 179 例. 手術統計は，耳疾患 $6 \%$ ，鼻・副鼻腔疾患 $25 \%$ ，口腔・咽頭・唾液腺疾患 $59 \%$ ， 喉頭・頸部・食道疾患11\%であった。内訳ではそれぞれ， 鼓室形成術，内視鏡下鼻内篩骨洞手術，口蓋扁桃摘出術， ラリンゴマイクロサージャーリーが最も多かった，悪性 腫瘍は 9 例（上咽頭 2，下咽頭 4，咽頭 3 ）で本年の死 亡退院は 5 例であった。質問 春田 厚(宮崎医大). 上咽腫 T4 症例の治療と経過は. 応答 上咽頭の原 発巣に $60 \mathrm{~Gy}$ ，頸部転移に対して $30 \mathrm{~Gy}$ 照射し，頸部郭清 術を施行した。更に，化学療法を行ったが，汎血球減少 から敗血症性ショックをきたした。

\section{済生会日向病院入院・手術統計}

(H 9，12 H10，11)

○鳥原康治・紀井登志哉・竹中美香（斉生会日向）

本年度の入院・手術統計をまとめて報告した。当科は 開設されて 5 年目となり日向近郊の他科病院からはめま いや顔面神経麻瘏, 頸部腫瘍などの紹介に加えて下顎 骨々折などの外傷, 頸部蜂窩織炎, 扁桃周囲膿瘍などの 紹介も増えてきた。また慢性中耳炎, 副鼻腔炎や耳下腺 腫瘍等の手術依頼も增え鼓室形成術，内視鏡下鼻内手術 が前年のほほ2 3 割件数が増加した。質問 松浦 宏司(県立宮崎)。県立延岡病院が改装されて, 救急疾患 が減少したということはないか。応答 急患の数は 
前年と比較して増加しており，日向市内の救急輪番の病 院からの紹介が多い.

\section{県立日南病院耳鼻咽喉科入院統計}

○稲葉順子・小池弥生・市原次郎（県立日南）

平成 9 年 12 月より平成10年11月までの入院統計を行っ た.入院患者は年間 226 人で 1 日平均では8.1人であった。 疾患別では耳疾患 $24.8 \%$, 鼻疾患 $14 \%$, 口腔咽頭疾患 $45.5 \%$ ，喉頭疾患 $10.3 \%$ ，頸部疾患 $5.4 \%$ であった。悪性 疾患は全疾患の $7.7 \%$ であった。当院では平成 10 年 5 月よ り放射線治療を開始したが，治療をした症例は，上顎癌 1 例, 中咽頭癌 2 例, 下咽頭癌 1 例, 喉頭癌 2 例の計 6 例であった。死亡退院は 4 例であった。質問 宮永 さとし(宮永 ENTクリニック)，下咽腫例は放射線の影 響による癌の可能性はあるか。前回 Radiation 範囲との 重複はあったか。応答 前回の照射は今回の照射部 位と重なる部分がある．今回の下咽頭癌は梨状陥山型で あるが，10年前の放射腺により，発生した可能性もある。

\section{感音難聴症例の内耳 3 次元 MRI 所見}

○大橋 充・清水謙祐・東野哲也・牛迫泰明 小宗静男（宮崎医大）

今回我久は, 平成 8 年 10 月から平成 10 年 8 月までに撮 像された感音難聴患者 129 例の内耳 3 次元 MRI 像の所 見を検討した。129例258耳中27耳に描出異常を認めた。

質問 松浦宏司(県立宮崎)。この方法では加齢による変 化（変性）については考虑しているか。応答 今回 は,加齢と画像所見との関連については検討していない. 撮像を行った患者の年齢はさまざまなので，今後検討を 加えてみたいと思う。

\section{拍動性耳鳴症例における臨床的検討} 堀之内謙一 (千鳥橋病院)

平成 9 年 1 月からの 1 年半に, 拍動性の耳鳴, 頭鳴を 主訴に当科を受診した 20 症例のうち 4 例に特街的な血管 病変 (脳動脈瘤, 頸動脈走行異常, 硬膜動静脈奇形, 胸 部大動脈瘤）が確認され，拍動性耳鳴症例には慎重な対 処が必要であると思われた。側頭骨 CT では高位内側型 頸静脈が耳鳴側に限られていた以外に特幑的な所見は認 められなかった．全例が冠危険因子を有し，動脈硬化が 拍動性耳鳴の素因の一つと考えられた。質問 小宗 静男 (宮崎医大)。原因不明の拍動性耳鳴の患者のうち, 患側の頸動脈圧迫で耳鳴が減弱する人数はどれ位か. 応答 拍動性耳鳴の自党のあった 3 例のうち 2 例は頸部 圧迫での拍動性自鳴の自賞, 他覚的聴取ともに軽快した。 質問 定永正明(宮崎市)。治療はどのようにしている か. 応答 報告した 4 症例のうち第 1 例怯脳動脈瘤 の clipping を行ったが術後も耳鳴は残った. 他の症例は 手術をせずに経過観察となったが，血圧のコントロール
で耳鳴の自覚は軽快した。質問 森満 保(宮崎医 大). 報告例中に他覚的耳鳴例が何例もあったか。応 答 呈示した症例 1 は両眼窩と頸部で，また症例 2 は両 眼窩で聴診器により他覚的耳鳴を聴取した。

耳介に生じた結節性筋膜炎の 1 例

○牧元 宏・永井知幸 (国立都城)

私たちは小児の耳甲介腔に生じた結節性筋膜炎を経験 した。外来にて 2 度生検を行ったが病理診断㹥炎症性の 肉芽であった。外来にて炎症を抑える局所処置を行って いたが，腫熘は急速に増大し家族の希望にて全摘手術を 施行した，病理は結節性筋膜炎であった。この疾患は発 症から急に大きくなり，本疾患は悪性腫瘍との鑑別が問 題となる，治療は全摘出するだけで十分とされる，私た ちは診断に苦慮した耳介の結節性筋膜炎の症例を報告し た。質問 小宗静男(宮崎医大)。頭頸部での発生率 (報告例) はどの位あるか。応答 諸外国の報告では， 頭頸部は全体の10〜20\%を占めている。質問 春田 厚 (宮崎医大)．1）頭頸部領域ではどのような部位に認 められるか．2）組織像では血管に富んだ所見はなかっ たか。応答 耳鼻科領域では耳下腺, 気管, 顔面皮 膚から発生した報告がある。呈示した病理スライドは, 血管に富んでいないが，生検した時出血が多く，止血に 苦労した.

\section{外転神経麻瘦を合併した副鼻腔桽胞症例}

○紀井登志哉・鳥原康治（済生会日向）

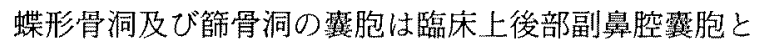
称される. 成因㹥鼻腔への開口部の閉鎖汇より粘液貯留 をきたし，副鼻腔が拡大した二次的裂胞が大部分を占め る。拢大した後部副鼻腔警胞㹥骨壁が菲薄な視神経隆起 を圧迫して視力障害, 視野障害などを引き起こすことが 多い，今回経験した症例は脳幹から出た外転神経が蝶形 骨洞を破って頭蓋内にまで進展した献胞により直接脳幹 部が圧排を受け生じたまれな症例だった。質問 定永正之(古賀総合)。1）外転神経麻軒が単独で起こり, 脳幹左道による脳虚血, 神経症状等は起こらなかったか。 2）䯣膜炎等感染による影響は全く考元られなかったか. 応答 1）神経学的な異常はなかった．2）䚙膜炎の症状 はなかった。質問 小宗静男(宮崎医大)。神経路の 圧迫がとれたため外転麻痺がとれたと考えているが，そ のような状態が圧迫がとれただけで速やかに回復するの か. 応答 脳幹以外の部分の原因による外転神経圧 迫も可能性はあるが，少ないように思われる。追加 定永正明(宮崎市)。外転神経麻痺は脳神経の中では一番 fragileで侵され易い，原因がなくなると自然に修復する ものであるという印象が強いように思う。追加 森満 保(宮崎医大)。ルンバール穿刺で髄液排除量が多 
すぎると外転神経麻痺のみ生じると聞いている．本例も 圧迫によると考えても良いと思う。

\section{耳鼻咽喉科領域の筋上皮腫 2 症例}

○竹中美香 - 外山勝浩 (県立延岡)

外分泌腺の介在部にある筋上皮腫細胞に由来するまれ な腫怕である筋上皮腫を頭頸部領域に 2 例経験したので 報告した。症例 1,72 歳女性, 左耳下部痛出現, 耳下部 に径 $2 \mathrm{~cm}$ の腫瘤を触知. CT で耳下腺内に石灰化を伴う 高吸収域の腫瘤を認め, 耳下腺浅葉摘出術を施行。病理 組織は筋上皮腫, 免疫染色はケラチン, S-100 蛋白で陽性 であった，左耳下部痛は消失，5力月間経過良好であっ た. 症例 2,62 歳男性, 平成 8 年 6 月左視力低下を自覚, 平成 9 年 3 月初診. 左視神経は萎縮し光覚はなかった。 CTで蝶形骨洞中心に頭蓋底を破壊する径 $6 \mathrm{~cm}$ の腫瘤 を認め, MRI では強く硬膜を圧排しており, 笁骨洞, 左 眼後方, 上咽頭側壁から副咽頭間隍にも進展, 生検で悪 性を思わせる筋上皮腫，免疫染色は $\alpha$-smooth muscle actinで陽性. 放射線療法 60Gy を行った。腫瘍は著明に 縮小し 1 年6力月経過良好である。質問 松浦宏司 (県立宮崎). 症例 1 と症例 2 では画像診断も治療法も異 なり，組織型も異なるような印象を受けるが，同じ筋上 皮腫の中でバリエーションがあるということか. 応 答 筋上皮腫は基本的には良性腫晹であるが，細胞の悪 性度により悪性と判断される症例もある.

\section{中咽頭・煩粘膜腫瘍の検討}

○井藤 健・松浦宏司・中島崇博・坪井陽子 (県立宮崎)

扁平上皮癌症例 24 例について検討した。女性は 1 例, 平均年齿は62.3歳であった. $\mathrm{TN}$ 分類では $\mathrm{T} 2$ 症例が多 く10例初診時頸部転移認めたものが 9 例であった。治療 は放射線療法全例施行. 2 年間制御できたものを効果あ りとし上壁は $100 \%$, 側壁で $60 \%$ あっあたが前壁では効果 が低かった。再発率高いため現在の治療として1期で レーザー手術. 30Gy 照射時に効果判定し手術または追 加照射を行っている. 質問 定永正之(古賀総合). 局所再発のない頸部再発が 2 例あったが，初回治療時の 頸部放射線照射野との関係はどうだったか. 応答 この 2 例は経過観察中. 他部位に再発を認めており，そ れが転移したものと考える。質問 小宗静男(宮崎医 大). 1）術前の単独化学療法はあまり意味がないので はないか. 2) 術前化学寮法のプロトコールについてそ の理論的根拠はどうなっているか. 応答 1) 頭頸 部癌の統計をみると頸部りンパ節転移からの再発が多 かったために，その抑制効果を期待して化学療法を行っ た. 病院全体の癌治療プロトコールに準じた。

ラリンゴマイクロサージェリー後に脳梗塞
をきたした 1 症例

○小池弥生・稲葉順子・市原次郎・西浦美佐子 (景立日南)

ラリンゴマイクロサージェリー後, 脳梗塞をきたした 症例を報告した，原因として，高齢，肥満，脱水，動脈 硬化，頸部伸展などが考えられた，予防には，十分な補 液，頸部血管の聴取などを心掛けると共に術中の急激な 血圧変動を避け，術後の止血剤は必要最小限にとどめる 必要があると思われる，術後の麻酔覚醒の遅延，脳血管 障害を疑わせる症状が出現したときは，早急にCT を行 い, 診断, 治療に当たることが大切と考えられた。質 問 春田 厚(宮崎医大)。CTで脳梗塞が疑われるのは どのくらいからか. 応答 脳梗塞では発症直後は等 吸収として摘出されるが, 発症後数時間を経て低吸収像 となる。質問 東野哲也(宮崎医大)，1）報告症例 のような高齢者に限れば，合併症の頻度は更に高いので はないか．2）報告例でみられた頸部雑音の原因は何か. 応答 1）玉熊ら, Haug らによると, 術後脳血管障害の 発生頻度は60歳以上の老人手術の $0.2 \sim 1.1 \%$ との報告 がある.2）症状が比較的軽く，数日間で軽快しており， 血管造影等の精査は行っていないので原因は分からない.

\section{扁桃摘出と皮膚疾患（特に掌蹠膿疮症）治療 の遠隔成績}

○定永正明（宮崎市）東 久美子・中野俊二 成田博美・田崎高伸（宮崎市皮膚科）

平成元年 1 月〜平成 10 年 4 月迄紹介された皮夙疾患の ため104名の扁摘を行い追跡し得た75名について調べた。 術前症状を10とし，10〜8 割改善を著効， $7 \sim 2$ 割改善 を有効， $0 \sim 1$ 割を不変，術前より増悪したものを悪化 とした。全体として著効 $59 \%$ ，有効 $19 \%$ ，計 $76 \%$ に改善 がみられた，掌蹠膿疱症のみでは著効 $67 \%$ ，有効 $14 \%$, 計 $81 \% に$ 改善がみられた。その他の皮膚疾患（多形滲出 性紅玨, 結節性紅斑, 滴状乾癬, 尋常性座瘡など)では 65\%の改善率であった。悪化した症例は 1 例もなかった。 掌蹠膿疮症の発症機序に考察を加え，具体的に 8 症例を 供覽した，病巣感染症として扁桃炎を診ることの意義を 強調し，早期に扁桃摘出を行うことの有効性を確認した。 質問 東野哲也(宮崎医大). 宮崎医大では PPP や IgA 腎症例の大多数がそれぞれ皮膚科, 内科より紹介される ようになってきたが，貴科で $\operatorname{Ig} A$ 督症の例も多くなった か. 応答 $\operatorname{IgA}$ 腎症はあまり内科から紹介されてい ないので増えていない. 質問 河野浩万(宮崎医大). 1）掌蹠膿疱症以外の皮膚疾患はどのようなものがあっ たか、2）それらの疾患の術後増悪所見は観察されたか. 応答 1) 多型滲出性紅斑, 結節性紅斑, アトピー性皮 膚炎, 臸常性座瘡があった，2）掌蹠膿疱症ではよくみら 
れるが，その他の疾患では明らかではない。

\section{Managed care $と$ Day surgery}

宮永さとし（宮永 ENT クリニック）

Managed care, DRG/PPS が試行される中にあって， 患者サービスの向上を図るとともに安定した医療を行う にはDay surgery は最良の方策といえる. 患者費用負担 の大幅軽減, 早期社会復㷌, 人件費や他固定費の削減, 在院日数の短縮, 定額報酬下における効率性向上が望め る. Day surgery を導入するには患者への説明の強化と 手術時期の選定と術後管理の徹底を図る必要がある。こ の 1 年の Day surgery の経験では鼓室形成術（慢性中耳
炎44例，真珠腫性中耳炎 5 例）においては入院加療時と 比較して総点数の 6 割減, 鼻内副鼻腔手術（鼻内篩骨洞 手術64例, 鼻内上頡洞手術 24 例) においては 7 割減となっ た。質問 定永正明(宮崎市)。扁摘や鼻副鼻腔手術 などで後出血の恐机がある場合の対応は。応答 頸 部手術, 歯撂切開を伴う副鼻腔疾患等術後入院加療を要 すと考えられる疾患は適応外と考えている.

特別講演

めまい診断と眼球運動記録 八木聰明（日医大）

\section{第267回大阪地方連合会}

\section{平成10年12月12日（土）一へキスト・マリオンルセル大阪支店10 F ホール}

\section{過重力負荷の耳石器に対する影響}

○宇野吉裕・堀井 新・長谷川太郎・久保 武 （阪大）梅本匡則（兵庫医大）

獤村貞治（市立堺）

重力負荷のラット耳石器に与える影響を，耳石の基質 蛋白質であるオステオポンチン (OPN) の mRNA 発現 を指標として検討した.まず RT-PCR 法にて球形囊, 卵 形製において OPNmRNA が発現していることを確認 した。続いて $2 \mathrm{G} ， 2$ 時間重力負荷の球形虂の OPNmRNA 発現に対する影響を, real time quantitative PCR 法を用いて定量したが，有意な変化は認めなかった。

警動物聴覚系におけるグルタミン酸受容体の変化

○長谷川太郎・土井勝美・布施㡏香・宇野吉裕

藤井和敏・久保 武 (阪大)

失聴による聴賞路の可塑的な変化に対し,グルタミン 酸受容体の関与が示唆されている。そこで，我々は失聴 によるラット蝸牛のグルタミン酸受容体の変化につい $\tau$, perkin elmer 社の ABI7700という装置を用いて研 究を行った。正常群では聴力獲得後, NRI, GluR2, およ びGluR3の各受容体の mRNA の発現量はほぼ一定で あるのに対し，失聴群では，時間経過と共に発現量が増 加していく結果が得られた。

\section{鼓膜穿孔における組織学的検討}

○小林正明・村田清高（近畿大）

ツチ骨に接して穿孔が存在する場合, 創傷治癒が遅延 することがある，遅延する理由を解明するために実験的 に鼓膜穿孔を作製した。鼓膜穿孔をツチ骨から離れて作 製した群と接して作製した群とに分けて比較した。後者 の方が，穿孔が閉鎖するまでの期間が長い．この場合，
鼓室側にも中間層増生が見られた。鼓室側にも中間層が 見られたことが，ツチ骨に接して穿孔が存在する場合に 創傷治瘑が遅延することに関連があると考えた。

\section{Treacher Collins 症候群の側頭骨病理所見}

○佐藤伸也・佐野光仁（母子保健センター）

Treacher Collins 症候群は第 1 鰓弓, 第 2 鰓弓の形成 不全が原因と考えられている疾患で，眼裂の外側下方へ の傾斜や煩骨，下顎骨の低形成を特徴とする. 今回, 機 会があり，側頭骨所見を報告した. Treacher Collins 症 候群の側頭骨標本の報告は少なく,今までの報告例では, 外耳道の閉鎖もしくは狭窄，中耳腔の分割やッチ骨，キ ヌ夕骨の変形, 欠損, アブミ骨の変形, 顔面神経の走行 異常が認められている。その一方で蝸牛や前庭, 半規管 などは有意な所見をほとんど認めない，本症例でも外耳 道, 耳小骨, 顔面神経の走行以外は明らかな異常を認め なかった。

環境生理におけるガソリン嗅素と鼻呼吸抵抗

○野富夫・鐘 杰夫（首都医大）

小山勝弘・辻田純三・佐々木貞雄・堀 清紀

(兵庫医大・第一生理)

大気污染物質として悪名高いガソリンの嗅素刺激に対 する鼻呼吸抵抗を検討した，正常な老齢者 30 名をペン大 のUPSIT嗅素刺激により, 測定器はNew Master (ICS). 測定は1996年 8 月より12月。ガソリン嗅素(NO) 刺激後に鼻呼吸の increase 型, 鼻呼吸の抵抗が記録され た.1998年度, ノーベル生理学医学賞はNOの血管拡張 作用の解明で受賞(U.S.A.)。よって本研究の体内作用は 割愛する。

OK432による鼻アレルギーの治療 